\title{
Subclinical gut inflammation in spondyloarthropathy patients is associated with upregulation of the E-cadherin/catenin complex
}

P Demetter, D Baeten, F De Keyser, M De Vos, N Van Damme, G Verbruggen, $S$ Vermeulen, M Mareel, D Elewaut, H Mielants, E M Veys, C A Cuvelier

\begin{abstract}
Objective-Previously an upregulation of E-cadherin and its associated molecules $\alpha$-catenin, $\beta$-catenin and plakoglobin has been demonstrated in clinically overt inflammatory bowel disease (IBD). The aim of this study was to investigate the expression of the E-cadherin/catenin complex in subclinically inflamed bowel mucosa from spondyloarthropathy (SpA) patients.

Methods-Ileal and colonic biopsy specimens from $19 \mathrm{SpA}$ patients with subclinical inflammatory gut lesions and from seven controls were stained with monoclonal antibodies against E-cadherin, $\beta$-catenin and plakoglobin and a polyclonal antibody against $\alpha$-catenin. E-cadherin mRNA was detected using a riboprobe. Inflammation was histologically classified into acute, chronic active and chronic quiescent forms.

Results-In acute and chronic active bowel inflammation of SpA patients, upregulation of the $\mathrm{E}$-cadherin/catenin glycoprotein complex could be observed. Chronic lesions in a quiescent state did not show such an upregulation. Furthermore, chronic inflammation was associated with an increase in E-cadherin mRNA.

Conclusions-As some of the SpA patients with subclinical gut inflammation develop IBD, upregulation of the E-cadherin/ catenin complex in inflamed bowel mucosa from SpA patients may point to early cellular changes in the development of IBD. However, at present it cannot be excluded that increased E-cadherin/ catenin complex expression is a bystander phenomenon of active inflammation.

(Ann Rheum Dis 2000;59:211-216)
\end{abstract}

In epithelial cells, homotypic homophilic intercellular adhesion is mediated by E-cadherin. ${ }^{1}$ This molecule is a transmembrane glycoprotein, mainly localised to the zonula adherens junctions of all normal epithelia. ${ }^{2}$ For normal function of E-cadherin, members of the catenin family ( $\alpha$-catenin, $\beta$-catenin and plakoglobin) are required. ${ }^{3}{ }^{4}$ Both $\beta$-catenin and plakoglobin $(\gamma$-catenin $)$ bind directly to E-cadherin; $\alpha$-catenin links the bound $\beta$-catenin or plakoglobin to the actin cytoskeleton, thereby forming complexes of either E-cadherin $/ \beta$ - catenin/ $\alpha$-catenin or of E-cadherin/ plakoglobin/ $\alpha$-catenin. ${ }^{5-8}$

Association between down-regulation of E-cadherin in cancers, high invasion rates and metastasis has been described..$^{9-11}$ Changes in the expression of E-cadherin associated catenins, in particular $\beta$-catenin, the vertebrate homologue of the Drosophila segment polarity gene armadillo, also frequently occur in early dysplastic lesions of the colon. ${ }^{7} 12$

Previously we demonstrated an upregulation of E-cadherin and its associated catenins in clinically overt inflammatory bowel disease (IBD) (P Demetter, submitted data). This up-regulation was detectable in acute as well as in chronic active gut inflammation. Dynamic changes in the expression of this complex might be important for the maintenance of normal epithelial integrity under inflammatory conditions

A prospective endoscopic and histological study of the terminal ileum and colorectum in 211 spondyloarthropathy (SpA) patients showed subclinical inflammatory gut lesions in $61 \% .^{13}$ Acute inflammation resembling acute infectious enterocolitis and a chronic type of ileocolitis were described. ${ }^{14}$ One third of the biopsy specimens featured chronic inflammation resembling Crohn's disease. After two to nine years, clinical and histological evidence of chronic IBD, particularly Crohn's disease, was found in $7 \%$ of patients, ${ }^{15}{ }^{16}$ suggesting early lesions of Crohn's disease in SpA patients.

The aim of this study was to investigate whether subclinical inflammatory gut lesions of $\mathrm{SpA}$ are also associated with an upregulation of the E-cadherin/catenin complex. This could indicate whether or not E-cadherin/catenin complex upregulation is an early event in the development of IBD.

\section{Methods}

TISSUE SPECIMENS

Twenty seven formalin fixed, paraffin wax embedded specimens from $19 \mathrm{SpA}$ patients featuring subclinically inflamed bowel mucosa were retrieved from the archival material of the Histopathology Department of the University Hospital in Gent. Blocks from seven patients with ileal lymphoid hyperplasia or irritable bowel syndrome were used as non-inflamed controls. All patients with SpA fulfilled the criteria of the European Spondyloarthropathy Study Group ${ }^{17}: 10$ of them suffered from ankylosing spondylitis, four from undifferentiated $\mathrm{SpA}$, three from reactive arthritis and two from 
Table 1 Clinical data of the investigated patients

\begin{tabular}{|c|c|c|c|c|c|c|}
\hline \multirow[b]{2}{*}{ Diagnosis } & \multirow{2}{*}{$\begin{array}{l}\text { Number } \\
\text { (patients) }\end{array}$} & \multicolumn{2}{|l|}{ Age } & \multicolumn{2}{|l|}{ Sex } & \multirow{2}{*}{$\begin{array}{l}\text { Localisation } \\
\text { of biopsy }\end{array}$} \\
\hline & & Median & Range & $M$ & $F$ & \\
\hline Normal & 7 & 42 & $21-48$ & 4 & 3 & $\begin{array}{l}7 \text { ileal } \\
6 \text { colonic }\end{array}$ \\
\hline SpA, acute gut inflammation & 6 & 33.5 & $24-41$ & 5 & 1 & $\begin{array}{l}4 \text { ileal } \\
2 \text { colonic }\end{array}$ \\
\hline SpA, chronic active gut inflammation & 10 & 26 & $12-46$ & 5 & 5 & $\begin{array}{l}7 \text { ileal } \\
4 \text { colonic }\end{array}$ \\
\hline SpA, chronic quiescent gut inflammation & 10 & 29.5 & $12-46$ & 6 & 4 & $\begin{array}{l}3 \text { ileal } \\
7 \text { colonic }\end{array}$ \\
\hline
\end{tabular}

juvenile $\mathrm{SpA}$. The disease group included 14 ileal and 13 colonic samples; the control group consisted of seven ileal and six colonic samples. Tables 1 and 2 summarise the patient data. The patients were mostly treated with non-steroidal anti-inflammatory drugs, in some cases combined with salicylazosulphapyridine. None of them took systemic corticosteroids.

\section{HISTOLOGICAL EVALUATION}

Haematoxylin and eosin stained slides of all specimens were divided into acute, chronic active or chronic quiescent inflammation. Criteria used were described previously. ${ }^{14}{ }^{18}$ In summary, acute inflammation is defined by the presence of neutrophils and/or eosinophils in the crypt and villus epithelium without alterations in the mucosal structure. In chronic active inflammation there is, in addition to architectural alterations, an active granulocytic infiltrate in the epithelium accompanied by an increased mononuclear cell infiltrate in the lamina propria. Chronic quiescent inflammation is characterised by structural changes only.

\section{IMMUNOHISTOCHEMISTRY}

Monoclonal antibodies against E-cadherin, $\beta$-catenin and plakoglobin (clones 36, 14 and 15 , respectively) were obtained from Transduction Laboratories (Lexington, USA), and a polyclonal anti- $\alpha$-catenin antibody (C-19) from Santa Cruz Biotechnology (Santa Cruz, USA). For unmasking of antigens, tissue sections $(5 \mu \mathrm{m})$ were immersed in $0.1 \mathrm{M}$ citrate buffer and heated in a microwave oven before applying the anti-E-cadherin, anti- $\alpha$-caterin and anti-plakoglobin antibodies. For the detection of $\beta$-catenin no pretreatment was applied. Immunoreactivity was visualised using New Fuchsin or 3-amino-9-ethylcarbazole (AEC), both obtained from Dako Corporation (Carpintera, USA). For the demonstration of E-cadherin, $\alpha$-catenin and plakoglobin a peroxidase method was used, whereas for the detection of $\beta$-catenin an alkaline phosphatase reaction was applied.

Negative controls consisted of duplicate sections stained simultaneously, in which the primary antibody was replaced by an isotype specific, irrelevant antibody.

EVALUATION OF IMMUNOHISTOCHEMICAL

STAINING INTENSITY

After examining the control cases, the SpA gut biopsy specimens were studied by two observers (PD and CAC). As in some cases inflammatory changes were rather striking, real blind reading was not attempted. Differences in the expression of the studied molecules were indicated only if both observers agreed. In focal inflammation the inflamed areas were compared with non-inflamed mucosa in the same biopsy sample.

\section{IN SITU HYBRIDISATION}

The expression of E-cadherin mRNA was examined by in situ hybridisation for the following situations: acute ileitis $(n=1)$, acute colitis $(n=2)$, chronic active ileitis $(n=3)$, chronic quiescent ileitis $(n=1)$, chronic quiescent colitis $(n=1)$, normal ileum $(n=3)$ and normal colon $(n=3)$. cRNA probes were generated in vitro according to the method described by Logel et al. ${ }^{19}$ The transcription primers span a 250 bp region of E-cadherin cDNA (purchased from Gibco BRL, Gent, Belgium). The E-cadherin specific sense primer was modified 5' terminally with a $\mathrm{T} 7$ promoter consensus sequence, 5'-CCAAGCTTCTAATACGACT C ACTATAGGGAGATCACTGACACCAA CGATAATCC-3'. The E-cadherin specific antisense primer was modified 5' terminally with a T3 promoter consensus sequence, 5'-CAGAGATGCAATTAACCCTCACAAA GGGAGAGTTGGCAGTGTCTCTCCAAA

Table 2 Clinical characteristics of spondyloarthropathy patients included in this study

\begin{tabular}{llllllll}
\hline Patient & Sex & Age & SpA subgroup & Ileal inflammation & Colonic inflammation & Endoscopy & $\begin{array}{l}\text { Treatment at } \\
\text { biopsy taking }\end{array}$ \\
\hline 1 & M & 24 & AS & acute & chronic quiescent & normal & none \\
2 & M & 29 & AS & acute & chronic quiescent & normal & NSAID \\
3 & M & 38 & AS & acute & none & normal & NSAID \\
4 & F & 26 & ReA & acute & none & normal & NSAID \\
5 & M & 40 & ReA & none & acute & normal & NSAID \\
6 & M & 41 & AS & none & acute & lesions & NA \\
7 & M & 26 & USpA & chronic active & chronic active & lesions & none \\
8 & F & 46 & USpA & chronic active & chronic quiescent & normal & NSAID \\
9 & M & 12 & JSpA & chronic active & chronic quiescent & normal & NSAID \\
10 & F & 33 & AS & chronic active & chronic quiescent & lesions & NSAID \\
11 & F & 29 & ReA & chronic active & chronic quiescent & lesions & NSAID \\
12 & F & 22 & USpA & chronic active & chronic quiescent & lesions & NSAID \\
13 & M & 26 & AS & chronic active & none & lesions & NSAID/SASP \\
14 & M & 23 & AS & none & chronic active & lesions & NSAID \\
15 & M & 23 & USpA & no biopsy & chronic active & lesions & NSAID \\
16 & F & 31 & AS & no biopsy & chronic active & lesions & NSAID/SASP \\
17 & M & 30 & JSpA & chronic quiescent & none & lesions & NSAID \\
18 & M & 32 & AS & chronic quiescent & no biopsy & normal & NSAID/SASP \\
19 & M & 40 & AS & chronic quiescent & no biopsy & lesions & none \\
\hline
\end{tabular}

AS: ankylosing spondylitis; JSpA: juvenile spondyloarthropathy; NA: not available; NSAID: non-steroidal anti-inflammatory drugs; ReA: reactive arthritis; SASP: salicylazosulphapyridine; USpA: undifferentiated spondyloarthropathy. 
TC-3'. This primerset was used in a PCR reaction on plasmid pMS13 containing E-cadherin cDNA. ${ }^{20}$ The PCR product was generated with AmpliTaq Gold (Perkin Elmer, Branchburg, USA) in a Programmable Thermal Controller100 (MJ Research, Watertown, USA) and then purified with an RNAse free Qiagen gel extraction kit (Qiagen GMBH, Hilden, Germany). Sense and antisense cRNA were transcribed and labelled with FITC-UTP in an RNA labelling kit (Boehringer Mannheim, Mannheim, Germany).

Paraffin wax sections of the tissues were hybridised with antisense RNA or sense RNA for 18 hours at $55^{\circ} \mathrm{C}$. After hybridisation they were incubated with an anti-FITC antibody (BioGenex, San Ramon, USA) at room temperature for 20 minutes. Colour reaction was developed using New Fuchsin.
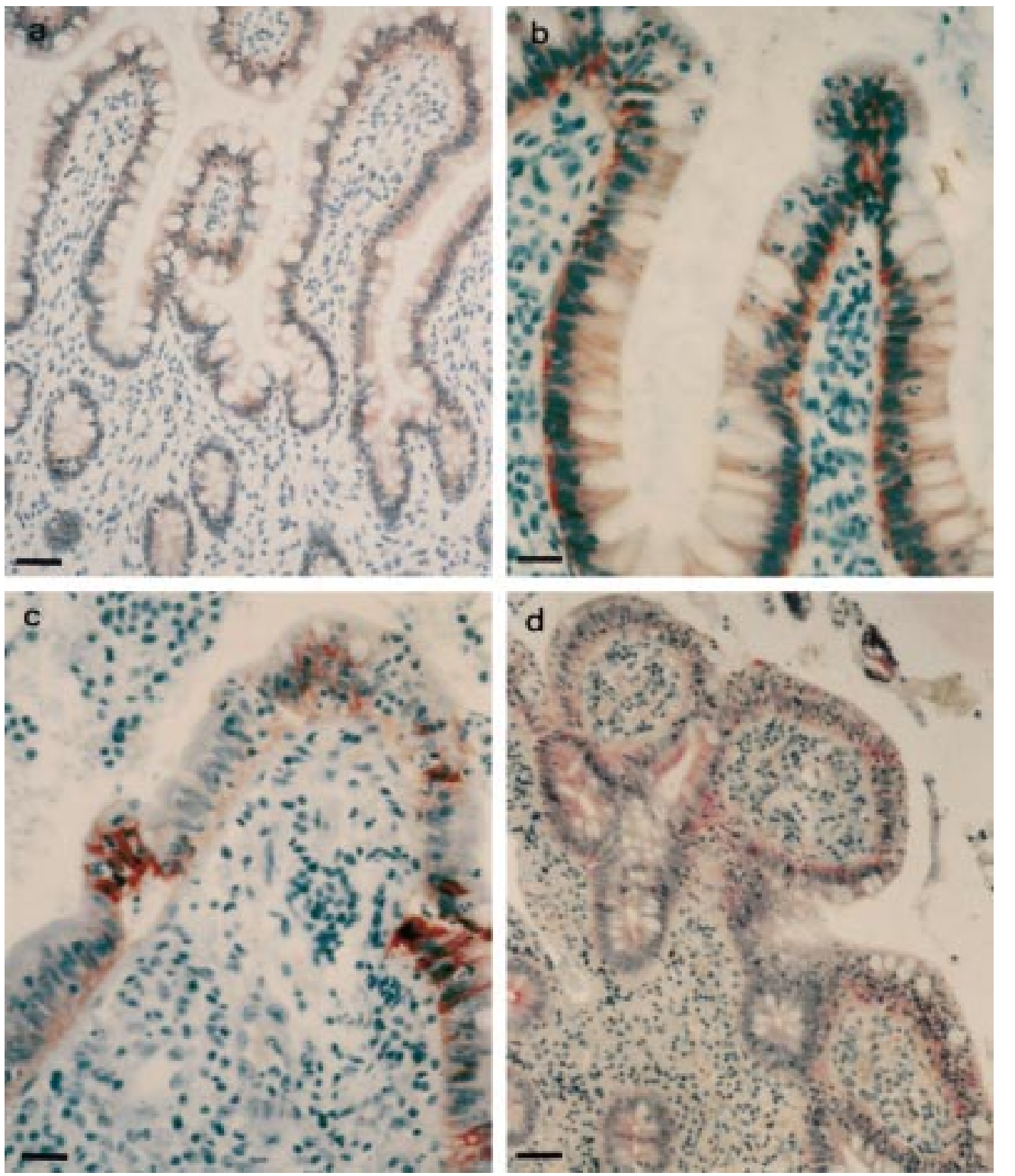

Figure 1 E-cadherin/catenin immunoreactivity in normal and subclinically inflamed bowel mucosa. (a): Weak a-catenin expression in non-inflamed ileum. (b): Acute ileitis showing strong expression of a-catenin in all cells of the villi. (c): Focal upregulation of E-cadherin in villus epithelial cells in chronic active ileitis. (d): $\beta$-catenin immunoreactivity in villus and crypt cells in chronic active ileitis. (a) and (c) Bar $=40 \mu \mathrm{m}$; (b) and (d) bar $=25 \mu \mathrm{m}$.

\section{Results}

IMMUNOHISTOCHEMISTRY

In normal ileum, positivity for E-cadherin and associated catenins presented as a distinct basolateral staining of the cells in the villi, especially in villous tips. Weak cytoplasmic staining was found in some instances. In crypts, staining was most prominent in the crypt base cells whereas other crypt cells expressed lower E-cadherin levels. For the associated catenins a similar pattern was found (fig 1a).

In comparison with ileum, the colonic epithelial cells showed stronger expression of the E-cadherin/catenin complex. As in ileum, crypt cells stained weaker than superficial epithelial cells.

In acute and in chronic active subclinical gut inflammation of $\mathrm{SpA}$ patients we found focal

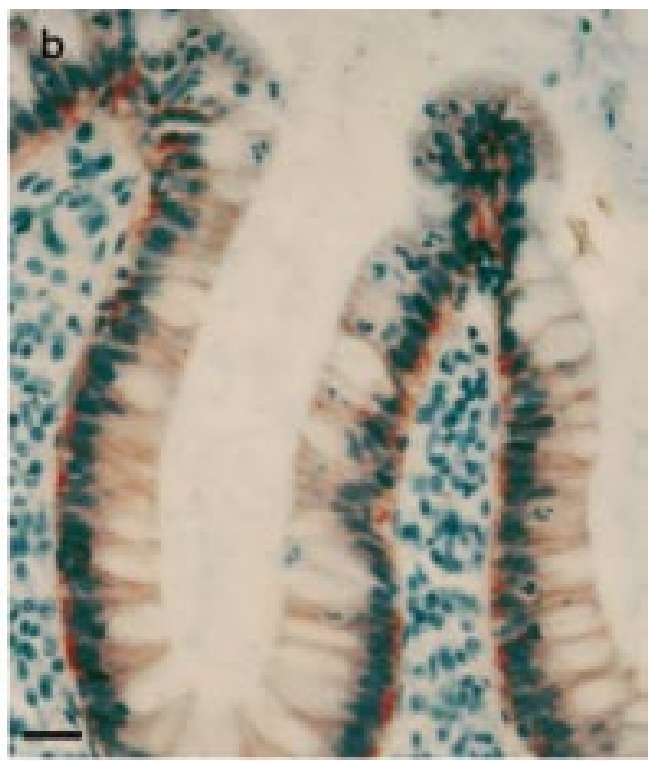


Table 3 Upregulation of E-cadherin/catenin complex in the different groups

\begin{tabular}{|c|c|c|c|c|c|}
\hline Patient & Localisation & E-cadherin & a-catenin & $\beta$-catenin & plakoglobin \\
\hline \multicolumn{6}{|c|}{ Acute inflammation } \\
\hline 1 & ileum & $\Uparrow$ & $\Uparrow$ & $\Uparrow$ & $\Uparrow$ \\
\hline 2 & ileum & $\Uparrow$ & $\Uparrow$ & $=$ & $=$ \\
\hline 3 & ileum & $\Uparrow$ & $\Uparrow$ & $=$ & $\Uparrow$ \\
\hline 4 & ileum & $\Uparrow$ & $=$ & $\Uparrow$ & $\Uparrow$ \\
\hline 5 & colon & $\Uparrow$ & $\Uparrow$ & $\Uparrow$ & $=$ \\
\hline 6 & colon $\star^{\star}$ & $=$ & $=$ & $=$ & $=$ \\
\hline \multicolumn{6}{|c|}{ Chronic active inflammation } \\
\hline 7 & ileum & $=$ & $\Uparrow$ & $\Uparrow$ & $\Uparrow$ \\
\hline 7 & colon & $\Uparrow$ & $=$ & $=$ & $\Uparrow$ \\
\hline 8 & ileum & $\Uparrow$ & $\Uparrow$ & $\Uparrow$ & $=$ \\
\hline 9 & ileum & $\Uparrow$ & $=$ & $=$ & $=$ \\
\hline 10 & ileum & $\Uparrow$ & $\Uparrow$ & $\Uparrow$ & $=$ \\
\hline 11 & ileum & $\Uparrow$ & $\Uparrow$ & $\Uparrow$ & $\Uparrow$ \\
\hline 12 & ileum & $\Uparrow$ & $\Uparrow$ & $\Uparrow$ & $=$ \\
\hline 13 & ileum & $\Uparrow$ & $\Uparrow$ & $\Uparrow$ & $\Uparrow$ \\
\hline 14 & colon & $\Uparrow$ & $=$ & $=$ & $=$ \\
\hline 15 & colon & $\Uparrow$ & $=$ & $=$ & $\Uparrow$ \\
\hline 16 & colon & $\Uparrow$ & $\Uparrow$ & $=$ & $\Uparrow$ \\
\hline \multicolumn{6}{|c|}{ Chronic quiescent inflammation } \\
\hline 1 & colon & $=$ & $\Uparrow$ & $\Uparrow$ & $=$ \\
\hline 2 & colon & $=$ & $=$ & $=$ & $=$ \\
\hline 8 & colon & $=$ & $=$ & $=$ & $=$ \\
\hline 9 & colon & $=$ & $=$ & $=$ & $=$ \\
\hline 10 & colon & $\Uparrow$ & $=$ & $=$ & $=$ \\
\hline 11 & colon & $\Uparrow$ & $=$ & $=$ & $=$ \\
\hline 12 & colon & $=$ & $=$ & $=$ & $=$ \\
\hline 17 & ileum & $=$ & $=$ & $=$ & $\Uparrow$ \\
\hline 18 & ileum & $=$ & $=$ & $=$ & $=$ \\
\hline 19 & ileum & $=$ & $=$ & $=$ & $=$ \\
\hline
\end{tabular}

^No cryptitis.

upregulations of the molecules of the E-cadherin/catenin complex. This focality was linked to the intensity of inflammation, with stronger immunoreactivity in cells in more inflamed areas. Especially cells adjacent to epithelial breaches were strongly positive. In crypts and in superficial epithelium, invasion with inflammatory cells, in particular neutrophils but also lymphocytes, was associated with more intense staining (fig $1 \mathrm{~b}-\mathrm{d}$ ). In chronic inflamed mucosa in a quiescent phase the expression of the E-cadherin/catenin complex resembled the findings in control biopsy specimens. In this condition focal changes in expression were only rarely seen. Results are presented in table 3.

IN SITU HYBRIDISATION

The labelling with the E-cadherin antisense mRNA probe showed strong mRNA positivity in both chronic active and chronic quiescent inflammation (fig 2a). Focal inflammation was accompanied by strong $\mathrm{mRNA}$ positivity in the adjacent area (fig $2 \mathrm{~b}$ ). In acute inflammation, however, the detectable expression was weak to negative, as in normal colon and ileum (fig 2c).

Regardless of the inflammatory state, the E-cadherin mRNA signal was found in a pattern compatible with that of the protein expression, with strongest positivity in crypt bases and superficial epithelial cells.

\section{Discussion}

In this study we demonstrate an increased expression of the proteins of the E-cadherin/ catenin complex in acute and chronic active subclinical gut inflammation in SpA patients. In chronic quiescent inflammation this upregulation was rare to absent. These findings are also seen in full blown IBD. ${ }^{21}$

Previously we found another similarity between IBD and SpA bowel mucosa. Flow cytometric analysis of $\mathrm{T}$ cells expanded from

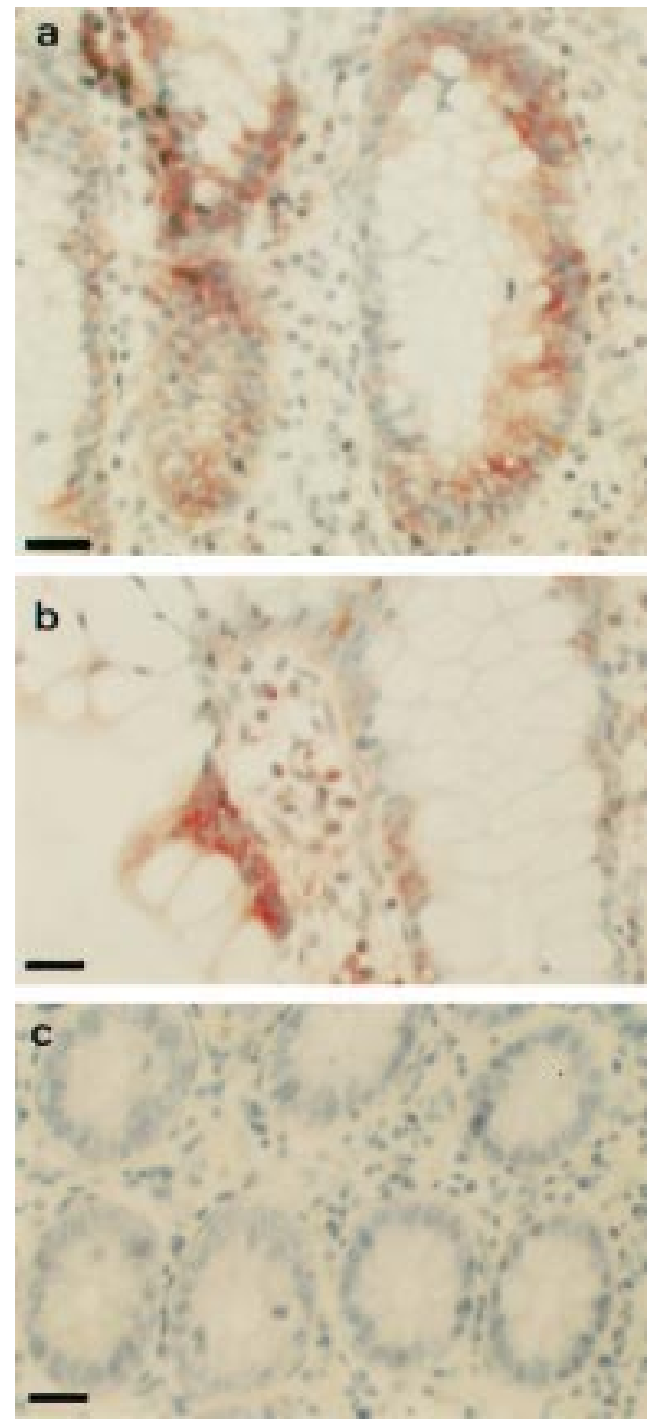

Figure 2 E-cadherin $m R N A$ in situ hybridisation. (a): Strong positivity in chronic quiescent ileitis. (b): Focal upregulation in chronic quiescent ileitis. (c): Absence of detectable expression in normal colon. (a), (b) and (c) Bar $=25 \mu \mathrm{m}$.

colonic biopsy specimens was conducted from patients with SpA featuring normal gut histology, patients with Crohn's disease and ulcerative colitis, and controls. On these T cells, the expression of the $\alpha \mathrm{E} / \beta 7$ integrin, of which the $\alpha \mathrm{E}$ subunit is also known as CD103, was increased in IBD and non-inflamed bowel mucosa from SpA patients but not in controls. ${ }^{22}$

As E-cadherin is not only involved in homophilic epithelial cell-cell adhesion but is also a ligand for the $\alpha \mathrm{E} / \beta 7$ integrin on intra-epithelial $\mathrm{T}$ cells, ${ }^{23}$ these two changes in expression could be attributable to a hitherto unknown common environmental or genetic factor. Upregulation of E-cadherin might follow the changed expression of the $\alpha \mathrm{E} / \beta 7$ integrin, as this molecule is already upregulated in histologically normal bowel mucosa from SpA patients. ${ }^{22}$ However, the expression of the E-cadherin/catenin complex in the latter situation remains to be examined. Interestingly, about half of the SpA patients included in 
this study did not show any macroscopically detectable ileocolonoscopic abnormalities, possibly pointing to upregulation of the E-cadherin/catenin complex as an early cellular change in the development of IBD. Seventeen of 19 patients included in this study were followed up by our group during 10 years or more after initial biopsy taking. Three of them developed full blown Crohn's disease during this period: patients 2,15 and 16 (tables 2 and 3 ). Even in patient 2, ileocolonoscopy at time of subclinical histological gut inflammation was completely normal.

Effects on the expression of the E-cadherin/ catenin complex may be moderated by the effects of trefoil peptides, ${ }^{24}$ called "trefoil" because of their distinctive cysteine-rich three leafed primary stucture. ${ }^{25}{ }^{26}$ Trefoil peptides have been shown to be overexpressed in regions of the gastrointestinal tract particularly susceptible to mucosal damage, and are of potential functional importance in different inflammatory conditions in the gastrointestinal tract..$^{25}$ One of these molecules, intestinal trefoil factor 3, may modulate epithelial cell adhesion and survival by affecting the complexes between E-cadherin, $\beta$-catenin and associated proteins. ${ }^{24}$ Moreover, the cooperative interaction of trefoil peptides with mucin glycoproteins, secreted by goblet cells, protects gastrointestinal mucosa from a variety of insults. ${ }^{28}$ However, the sequential expression of spasmolytic polypeptide, intestinal trefoil factor, epidermal growth factor and transforming growth factor $\alpha \mathrm{mRNAs}$ in experimental ulceration in rat stomach makes clear that epithelial protection and restitution is a complex process. ${ }^{29}$ Anyway, the pronounced but temporally different patterns of mRNA induction after ulceration suggest that the trefoil peptides may fulfil immediate roles in the protection and restitution of epithelium.

Another molecule possibly involved in the upregulation of the E-cadherin/catenin complex is interleukin 12 (IL12), expressed and released by lamina propria mononuclear cells from patients with Crohn's disease. ${ }^{30}$ It has been shown that upregulation of IL12 production is a critical event in the initiation of bowel inflammatory lesions in Crohn's disease, ${ }^{31}$ which can evolve out of the subclinical gut lesions in SpA patients. ${ }^{15}{ }^{16}$ As IL12 upregulates E-cadherin expression, ${ }^{32}$ it may be involved in the alterations we described.

In chronic quiescent inflammation, we detected an increase in E-cadherin mRNA without upregulation of the protein. This might be caused by the action of the matrix metalloproteinase stromelysin-1, which is upregulated in chronic bowel inflammation. ${ }^{33} 34$ Stromelysin-1 possibly affects tissue repair at multiple stages. ${ }^{33}{ }^{34}$ However, it may cleave E-cadherin and make it disappear from cell-cell contacts. ${ }^{35}$

In conclusion, we found an upregulation of the E-cadherin/catenin complex in subclinical gut inflammation in SpA patients. The meaning, however, is not fully understood. As part of these patients evolve into clinically overt inflammatory bowel disease, our finding can suggest on the one hand that this upregulation may be of major importance in the pathogenesis of Crohn's disease or SpA, or both. On the other hand, hitherto it cannot be excluded that the upregulation is secondary to active, albeit subclinical, inflammatory bowel disease. If the binding between E-cadherin and the $\alpha \mathrm{E} / \beta 7$ integrin could be identified as crucial, therapeutic blocking approaches might be developed in the future to treat intestinal inflammation and SpA.

The authors wish to thank Dr Philip De Bruyne for preparation of the riboprobes. Dr Baeten is an FWO-Vlaanderen Research Assistant.

Funding: this work was supported by a concerted action grand GOA96001 of the University of Gent (Belgium), and an FWOVlaanderen grant 3.0028.95.

1 Takeichi M. Cadherin cell adhesion receptors as a morphogenetic regulator. Science 1991;251:1451-5.

2 Smith MEF, Pignatelli M. The molecular histology of neoplasia: the role of the cadherin/catenin complex. neoplasia: the role of the cadh

3 Ozawa M, Ringwald M, Kemler R. Uvomorulin-catenin complex formation is regulated by a specific domain in the cytoplasmic region of the cell adhesion molecule. Proc Natl Acad Sci USA 1990;87: 4246-50.

4 Nagafuchi A, Takeichi $M$. Cell binding function of E-cadherin is regulated by the cytoplasmic domain. EMBO 1988; 7:3679-84

5 Nathke IS, Hinck L, Swedlow JR, Papkoff J, Nelson WJ. Defining interactions and distributions of cadherin and catenin complexes in polarized epithelial cells. J Cell Biol 1994;125:1341-52.

6 Hinck L, Nathke IS, Papkoff J, Nelson WJ. Dynamics of cadherin/catenin complex formation: novel protein interaction and pathways of complex assembly. J Cell Biol 1997;125:1327-40.

7 Valizadeh A, Karayiannakis AJ, El-Hariry I, Kmiot W, Pignatelli $M$. Expression of

8 E-cadherin-associated molecules $(\alpha-, \beta$ - and $\gamma$-catenins and p120) in colorectal polyps. Am J Pathol 1997;150:1977-84.

9 Jou TS, Stewart DB, Stappert J, Nelson WJ, Marrs JA. Genetic and biochemical dissection of protein linkages in the cadherin-catenin complex. Proc Natl Acad Sci USA 1995;92:5067-71.

10 Bracke ME, Van Roy FM, Mareel M. The E-cadherin/ catenin complex in invasion and metastasis. In: Günthert $\mathrm{U}$, Birchmeier W, eds. Attempts to understand metastasis formation I. Berlin: Springer, 1996:123-61.

11 Takeichi $M$. Cadherins in cancer: implications for invasion and metastasis. Curr Opin Cell Biol 1993;5:806-11.

12 Mareel M, Bracke M, Van Roy F. Invasion promoter versus invasion suppressor molecules: the paradigm of E-cadherin. Mol Biol Rep 1994;19:45-67.

13 Inomata $M$, Ochiai A, Akimoto S, Kitano S, Hirohashi S. Alteration of $\beta$-catenin expression in colonic epithelial cells of familial adenomatous polyposis patients. Cancer Res 1996;56:2213-17.

14 Mielants H, Veys EM, Cuvelier C, De Vos M. Ileocolonoscopic findings in seronegative spondylarthropathies. Br J Rheumatol 1988;27:95-105.

15 Cuvelier C, Barbatis C, Mielants H, De Vos M, Roels H, Veys E. Histopathology of intestinal inflammation related to reactive arthritis. Gut 1987;28:394-401.

16 De Vos M, Cuvelier C, Mielants H, Veys E, Barbier F, Elewaut A. Ileocolonoscopy in seronegative spondylarthropathy. Gastroenterology 1989;96:339-44.

17 De Vos M, Mielants H, Cuvelier C, Elewaut A, Veys E. Long term evolution of gut inflammation in patients with spondylarthropathy. Gastroenterology 1996;110:1696-703.

18 Dougados M, van der Linden S, Juhlin R, Huitfeldt B, Amor $\mathrm{B}$, Calin A, et al. European spondylarthropathy study group preliminary criteria for the classification of spondylarpreliminary criteria for the classification of

19 Cuvelier C, Mielants H, De Vos M, Veys E, Roels H. Major histocompatibility complex class II antigen (HLA-DR) expression by ileal epithelial cells in patients with seronegative spondylarthropathy. Gut 1990;31:545-9.

20 Logel J, Dill D, Leonard S. Synthesis of cRNA probes from PCR-generated DNA. Biotechniques 1992;13:604-10.

21 Bussemakers MJ, van Bokhoven A, Mees SG, Kemler R, Schalken JA. Molecular cloning and characterization of the human E-cadherin cDNA. Mol Biol Rep 1993;17:123-8.

2 Demetter P, Cesmeli E, De Vos M, Bullock G, Van Damme $\mathrm{N}$, Baeten $\mathrm{D}$, et al. Upregulation of E-cadherin and associated molecules ( $\alpha-, \beta$ - and $\gamma$-catenins) in inflamed bowel mucosa. Gastroenterology 1998;114:A962.

23 Elewaut D, Van Damme N, Baeten D, Demetter P, Sas S, De Vos M, et al. Intestinal mucosa of patients with spondyloarthropathy is enriched with $\mathrm{T}$ cells carrying $\alpha \mathrm{E} \beta 7$ integrin, even in the absence of histologically defined inflammation. Gastroenterology 1999;116:A706.

24 Cepek KL, Shaw SK, Parker CM, Russell GJ, Morrow JS, Rimm DL, et al. Adhesion between epithelial cells and T lymphocytes mediated by E-cadherin and the $\alpha^{\mathrm{E}} \beta_{7}$ integrin. Nature 1994;372:190-3. 
25 Efsthathiou JA, Noda M, Rowan A, Dixon C, Chinery R, Jawhari A, et al. Intestinal trefoil factor controls the expres-
sion of the adenomatous polyposis coli-catenin and the sion of the adenomatous polyposis coli-catenin and the E-cadherin-catenin complexes in human colon car
cells. Proc Natl Acad Sci USA 1998;95:3122-7.

26 Wright NA, Poulsom R, Stamp G, Van Noorden S, Sarraf C, Elia G, et al. Trefoil peptide gene expression in gastrointestinal epithelial cells in inflammatory bowel disease. Gastroenterology 1993;104:12-20.

27 Poulsom R, Chinery R, Sarraf C, Lalani E-N, Stamp G, Elia $\mathrm{G}$, et al. Trefoil peptide gene expression in intestinal adaptation and renewal. Scand J Gastroenterol 1992;27 (supp 192): 17-28.

28 Wright NA, Poulsom R, Stamp GWH, Hall A, Jeffery RE, Longcroft JM, et al. Epidermal growth factor (EGF/URO) induces expression of regulatory peptides in damaged human gastrointestinal tissues. J Pathol 1990;162:279-84.

29 Kindon H, Pothoulakis C, Thim L, Lynch-Devaney K, Podolsky DK. Trefoil peptide protection of intestinal epithelial barrier function: cooperative interaction with mucin glycoprotein. Gastroenterology 1995;109: with mucir

30 Alison MR, Chinery R, Poulsom R, Ashwood P, Longcroft JM, Wright NA. Experimental ulceration leads to sequential expression of spasmolytic polypeptide, intestinal trefoil factor, epidermal growth factor and tronth factor alpha mRNAs in rat stomach. J Pathol 1995;175. 405-14.
31 Monteleone G, Biancone L, Marasco R, Morrone G, Marasco O, Luzza F, et al. Interleukin 12 is expressed and actively released by Crohn's disease intestinal lamina propria mononuclear cells. Gastroenterology 1997,112: $1169-78$

32 Parronchi P, Romagnani P, Annunziato F, Sampognaro S, Becchio A, Giannarini L, et al. Type 1 T-helper cell predominance and interleukin-12 expression in the gut of patients with Crohn's disease. Am J Pathol 1997;150:82332 .

33 Hiscox S, Hallet MB, Puntis MCA, Jiang WG. Inhibition of cancer cell motility and invasion by interleukin-12. Clin Exp Metastasis 1995;13:396-404

34 Bailey CJ, Hembry RM, Alexander A, Irving MH, Grant ME, Shuttleworth CA. Distribution of the matrix metalloproteinases stromelysin, gelatinases A and $B$, and collapene in Crohn's disease and normal intestine. J Clin Pathol 1994;47:113-16.

35 Saarialho-Kere UK, Vaalamo M, Puolakkainen P, Airola K, Parks WC, Karjalainen-Lindsberg M-L. Enhanced expression of matrylisin, collagenase, and stromelysin-1 in sion of matrylisin, collagenase, and stromelysin-1

36 Lochter A, Galosy S, Muschler J, Freedman N, Werb Z, BisLochter A, Galosy S, Muschler J, Freedman N, Werb Z, Biscascade of molecular alterations that leads to stable pithelial-to-mesenchymal conversion and a premalig phenotype in mammary epithelial cells. J Cell Biol 1997;139:1861-72. 